\title{
JOB STRESS AND MORTALITY IN OLDER AGE
}

\section{BEATA TOBIASZ-ADAMCZYK, PIOTR BRZYSKI, MARZENA FLOREK, and MONIKA BRZYSKA}

\author{
Jagiellonian University Medical College, Kraków, Poland \\ Chair of Epidemiology and Preventive Medicine
}

\begin{abstract}
Objectives: This paper aims to assess the relationship between the determinants of the psychosocial work environment, as expressed in terms of JDC or ERI models, and all-cause mortality in older individuals. Materials and Methods: The baseline study was conducted on a cohort comprising a random sample of 65-year-old community-dwelling citizens of Kraków, Poland. All of the 727 participants (410 women, $317 \mathrm{men}$ ) were interviewed in their households in the period between 2001 and 2003; a structured questionnaire was used regarding their occupational activity history, which included indexes measuring particular dimensions of their psychosocial work environment based on Karasek's Job Demand-Control model and Siegrist's Effort-Reward Imbalance model, as well as health-related quality of life and demographic data. Mortality was ascertained by monitoring City Vital Records for 7 years. Analyses were conducted separately for men and women, with the multivariate Cox proportional hazard model. Results: During a 7-year follow-up period, 59 participants $(8.1 \%)$ died, including 21 women $(5.1 \%$ of total women) and 38 men $(12 \%)(\mathrm{p}<0.05)$. Significant differences in the number of deaths occurred regarding disproportion between physical demands and control in men: those with low physical demands and low control died three times more often than those with high control, regardless of the level of demands. The multivariate Cox proportional hazard model showed that significantly higher risk of death was observed only in men with low physical demands and low control, compared to those with low physical demands and high control $(\operatorname{Exp}(\mathrm{B})=4.65,95 \% \mathrm{CI}$ : 1.64-13.2). Conclusions: Observed differences in mortality patterns are similar to the patterns of relationships observed in health-related quality of life (HRQoL) level at the beginning of old age; however, the relationship between efforts and rewards or demands and control and mortality was not fully confirmed.
\end{abstract}

Key words:

Job stress, Job demand, Job control, Efforts, Rewards, Mortality in older age

\section{INTRODUCTION}

The relation between job stress and negative health outcomes (especially in the case of morbidity and mortality in cardiovascular diseases) has been the longstanding focus of research interest over the last four decades [1-10]. This increasing research activity was supported, among others, by two theoretical models: Karasek's [11] two dimensional model of Job Demand-Control (JDC - job demands-decision latitude/control) and Siegrist's [12,13] Effort-Reward Imbalance model (ERI - work offers opportunities to acquire self-efficacy, self-esteem, self-integration). When an imbalance exists between high effort and low reward, the fulfillment of self-regulatory needs is jeopardised [14].

Huang et al. [15] state that current theories and models of job stress are characterised by major theoretical differences: in "transactional" models, such as the effort-reward imbalance model developed by Siegrist, the main focus is on the interaction of environmental stressors with worker attributes, coping style and resources within the work environment. In this model, critical coping (need for control and approval) based on intrinsic (personal) and extrinsic (situation) resources is associated with high effort (created by demands, obligations) in relation to low reward,

Received: August 10, 2012. Accepted: April 25, 2013

Corresponding author: B. Tobiasz-Adamczyk, Chair of Epidemiology and Preventive Medicine, Jagiellonian University Medical College, Kopernika 7, $31-034$ Kraków, Poland (e-mail: mytobias@cyf-kr.edu.pl). 
measured by money, esteem, status control (job stability, forced mobility, status inconsistency, blocked career).

In contrast, such models as Karasek's control-demand model of job stress focus on the role of the psychological demands, decision latitude (control) and support at work. Epidemiological studies performed in 5 European countries: The Somstress Study (Belgium), the GAZELCohort Study (France), the WOLF-Norrland Study (Sweden), the Whitehall II Study (UK), the Public Transport Employees Study (Germany), confirmed good psychometric properties of the scales measuring the effort-reward imbalance model at work [16].

Calnan [17] mentioned that Karasek's model was initially designed to assess the job stress among blue-collar industrial workers while the Effort-Reward Imbalance model was more useful for explaining the job stress in the occupations and professions involving provision of services, especially those dealing with person-based interactions (health professionals).

Studies focusing on combining the two models, which primarily emphasize various elements in the psychosocial work environment and their dimensions, have produced separate results. Calnan et al. [17] compared the predictive ability of the two models for explaining work stress and showed that current work environment is better explained by ERI model.

The relationship between job strain and depression, exhaustion and job satisfaction has been confirmed $[18,19]$. Ota et al. $[20,21]$ note that the effort-reward imbalance model (ERI) and demand-control-support model (DCS) describe the adverse psychological job characteristics related to insomnia; and are therefore more useful to identify workers at risk of insomnia. Roelen et al. [22,23] investigated whether perceived psychological and mental workload and specific job demands were associated with self-reported health complaints in a group of 983 male employees in manufacturing industry.
Kopp [24] found strong associations of variables characterising an adverse psychosocial work environment, as well as other socioeconomic and psychosocial variables, with variations of premature cardio-vascular (CV) mortality rates among middle-aged men and women in 150 sub-regions of Hungary. $\mathrm{Yu}$ [25] confirmed an independent effect of both the JDC and the ERI model on the well-being of 876 workers.

In a previous study [26], conducted in a sample of people at the beginning of old age, the authors showed that the characteristics of past psychosocial work conditions influenced the health-related quality of life. This effect was noted regardless of the model used to describe these relations (Karasek's job-demand-control or Siegrist's effortreward imbalance).

Job satisfaction was found to be lower in men with low physical demands and low control in comparison to men with low physical demands and high control. In women, job satisfaction was lower in individuals with low psychological demands and low control in comparison to those with low demands and high control. In terms of the effortreward imbalance model, only women with low efforts and low rewards (both physical and psychological) had significantly lower chances of job satisfaction than those with low effort and high reward. Life satisfaction was higher in men with high physical demands and high control in comparison to those with low physical demands and high control, while in terms of ERI model, a similar relationship was observed in women.

Self-rated health was lower not only in women with high psychological demands and high control, but also in men with high physical demands and low control in comparison to those with low demands and high control. However, when considered in terms of the ERI model, only in men were low rewards related to low self-rated health when compared to those with low physical efforts and high rewards. Karasek's model also indicated that women with high physical demands and low control were more functionally independent (i.e. independent in all everyday 
activities, identified by the scale) than those with low physical demands and high control, while in men it was low demands and high control that lowered the level of functional independence when compared to other groups. In terms of the ERI model, only men with high effort and low reward were at higher odds of functional independency in comparison to those with low effort and high reward. These results proved that psychosocial characteristics of previous work conditions had impact on the health-related quality of life and self-reported health status of men and women at the beginning of old age, and gave rise to a question whether they might also influence their risk of death [26].

Huang et al. [15] stress the difficulties in precisely conceptualizing and measuring the construct, and delineating the mechanisms by which job stress influences health outcomes. Evidence exists that perceptions of intensified workload, monotonous work, and low social support play a role in work-related upper extremity disorders. Some investigators have defined occupational factors in terms of subjectively experienced qualities of the work environment, others distinguish between the structural (objective) characteristics of work on the one hand and more subjective ones, such as worker perceptions of such characteristics, on the other.

The present paper aims to assess the relationship between psychosocial work conditions, as expressed in terms of a job stress model, partially based on the original dimensions of the JDC or ERI models, and mortality, adjusted for both the other indicators of the work environment and the health-related quality of life (Figure 1). An epidemiological approach has been used to evaluate the role of psychosocial job characteristics (job stress) in the follow-up study of mortality. The life course approach attempts to evaluate the role of the cumulative risk of a range of life activities (psychosocial dimensions of work activity) in explaining the role of health outcomes (mortality).

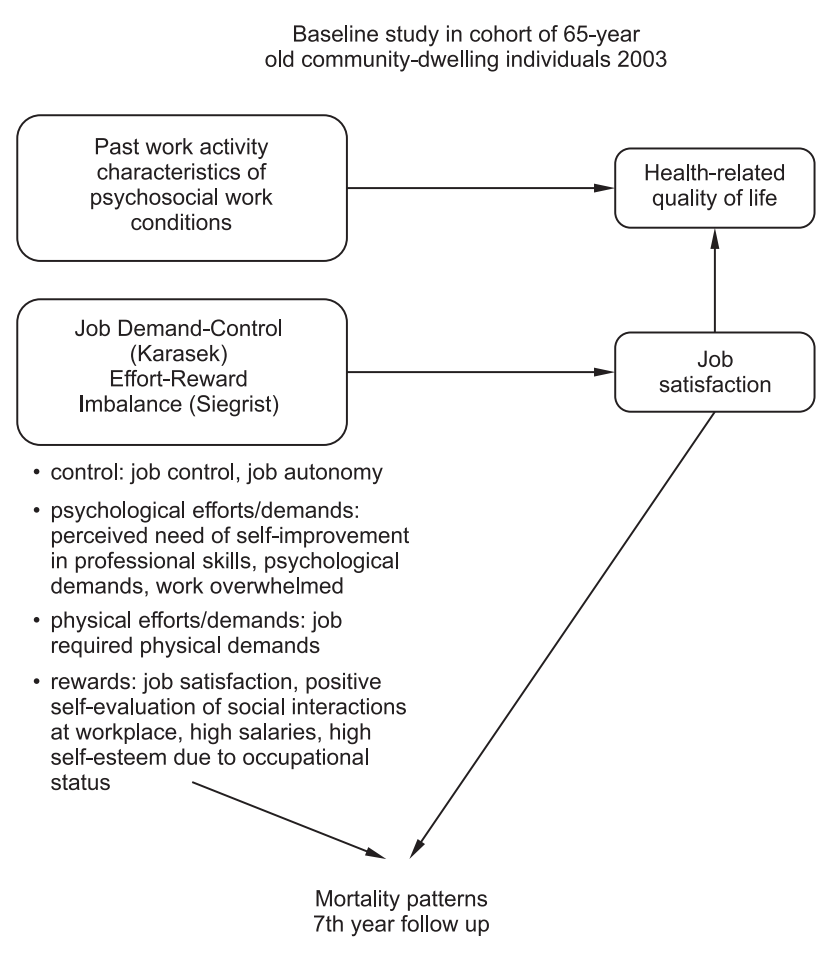

Fig. 1. Model of the study

\section{MATERIALS AND METHODS}

The baseline study was conducted in a cohort randomly sampled from the 65-year-old community-dwelling citizens of Kraków, Poland. All of the 727 participants (410 women, 317 men) were interviewed in their households, in the period between 2001 and 2003, by specially trained interviewers. A structured questionnaire was used to collect information on history of occupational activity (including psychosocial job characteristics) using the items presented below. Based on content analysis of these items they were combined into indexes measuring particular dimensions similar to those defined by Karasek in the Job Demand-Control (JDC) model and Siegrist in the Effort-Reward Imbalance model (ERI) [11,12,27]:

a) Psychological effort/demands (3 items, Cronbach $\alpha=0.62$ ): Did your job require continuous professional development? Did your job require a considerable 
amount of mental effort? Did you feel overwhelmed with your professional duties at work?

b) Physical effort/physical demands (2 items, Cronbach $\alpha=0.49$ ): Did your job require a considerable amount of physical effort? Did you perform your professional duties in an environment potentially harmful to health (noise, chemical pollution, radiation)?

c) Control ( 2 items, Cronbach $\alpha=0.84$ ): Were you able to make autonomous decisions about how you organized your work? Did you always have much to say about your work responsibilities?

d) Rewards (4 items, Cronbach $\alpha=0.61$ ): Did you feel satisfied with the professional work you performed? Did your professional work create opportunities for meeting nice and interesting people? Was your salary satisfying? Did you feel important performing your professional duties?

e) Lack of social support in the workplace ( 3 items, Cronbach $\alpha=0.51$ ): Was your job stressful? While performing your duties, did you experience serious conflicts with your co-workers/in your working team? Did others in your work environment experience conflicts which influenced your wellbeing?

f) Social interactions with co-workers (4 items, Cronbach $\alpha=0.72$ ): Do you still maintain social contacts with friends/colleagues at work? Do you participate in social events organized by your colleagues/friends from work? Do you visit your workplace willingly? Did you have a large group of friends at work?

Dichotomous answers to all above-mentioned items were coded as "yes" $=1$, "no" $=0$. As measures of job characteristics and outcome variables were not completely identical with the original scales, equivalent indicators were used. Certain indexes were defined as having a higher level when their value was equal to or higher than the median of distribution. Dichotomized values of indexes were combined into 4-category variables with the following categories: low demands-high control (reference category in regression models), high demands-high control, low demands-low control, and high demands-low control [26]. In the present analysis, categories representing the balance between physical efforts and rewards in women had to be combined into one category due to the small number of the deceased in one of these categories.

The health-related quality of life (HRQoL) was measured using the following indicators:

1. Self-rated health: one item with a 5-item Likert response scale from excellent (point $=5$ ) to poor ( point $=1)$ - in the Cox proportional hazard model, ranges from 3 to 5 were combined as being good self-rated health and from 1 to 2 as poor self-rated health.

2. Psychological well-being (Geriatric Depression Scale) [28] - in the Cox proportional hazard model, a score equal to or higher than 10 points was defined as severe depression.

3. Chronic conditions (CBS Chronic Conditions Shortened Version) [29] - in the Cox proportional hazard model, it was used as a binary variable, with three or more chronic conditions indicating a high number of chronic conditions.

4. Functional status (based on the Groningen Activity Restriction Scale) [30] in the Cox proportional hazard model, it was used as a binary variable indicating respondents independent in all functions identified by the scale.

5. Life satisfaction measured by means of Life Satisfaction Index A (LSI A) [31] - two separate indexes were distinguished from LSI A to measure life satisfaction with present life, and life satisfaction with earlier stages of life. In the Cox proportional hazard model, a higher level of life satisfaction was defined as a result higher than the median of the distribution.

Mortality was ascertained by monitoring City Vital Records until December 31st 2010 and all deaths had been recorded: all individuals from the database were 
checked using the records of Kraków citizens, both alive and dead.

\section{Statistics}

The strength of relationship between categorical variables was assessed with Cramer's V coefficient. The impact of divergences between JDC and ERI was analyzed using the multivariate Cox proportional hazard model. The assumptions of the Cox proportional hazard model were checked by inspecting log-log plots - the plotted lines were parallel. All analyses were conducted separately in men and women. Multivariate models were adjusted for all dimensions of HRQoL analyzed in a previous paper (self-rated health, number of chronic conditions, independence in functional status, psychological well-being and depression), as well as for other variables characterizing the work environment not included in our implementation of ERI or JDC models, such as the supervisor position and the income [26].

The impact of the characteristics of work environment conditions on mortality risk was also adjusted for demographical and social characteristics of respondents including marital status, living alone and the presence of children. The models were created starting from a univariate model including only one of the aspects of demand/ control or effort/reward relationship, respectively, and this variable was retained in all subsequent models. In the second step, models concerning physical demands (JDC) or physical efforts (ERI) were adjusted for level of psychological demands or efforts, respectively, while models concerning psychological demands (JDC model) or efforts (ERI model) were adjusted for level of physical demands or efforts, respectively. In the subsequent steps, all other confounding variables were added one by one. If these variables were significant at $p=0.10$ in at least one group of men or women, they were retained in the model used in the following step, otherwise they were omitted.

Statistical analysis was performed using IBM SPSS Statistics 20 for Windows.

\section{RESULTS}

Statistically significant differences were observed between men and women under baseline study concerning their education level - a higher percentage of women reported only primary or lower education; the occupational history of the women was significantly different from that of the men as well - a greater percentage of women finished their occupational career earlier, more men than women were involved in occupational activity as manual workers, and more men than women held a supervisor position (Table 1). Nine women (2.3\%) who

Table 1. Differences in demographic and occupational characteristics of respondents in the baseline study

\begin{tabular}{lrrrr}
\hline & Variables & \multicolumn{2}{c}{ Women } & \multicolumn{2}{c}{ Men } \\
\cline { 2 - 5 } & $\mathrm{n}$ & $\%$ & $\mathrm{n}$ & $\%$ \\
\hline Education $^{1}$ & & & & \\
$\quad$ primary school or less & 109 & 26.6 & 49 & 15.5 \\
$\quad$ vocational & 71 & 17.3 & 106 & 33.5 \\
secondary & 143 & 34.9 & 84 & 26.6 \\
$\quad$ university & 87 & 21.2 & 77 & 24.4 \\
Occupational history & & & & \\
$\quad$ never paid worker & 9 & 2.2 & 0 & 0.0 \\
$\quad$ former paid worker (retired) & 357 & 87.3 & 241 & 76.0 \\
$\quad$ continuation of occupational activity & 43 & 10.5 & 76 & 24.0 \\
\hline
\end{tabular}


Table 1. Differences in demographic and occupational characteristics of respondents in the baseline study - cont.

\begin{tabular}{|c|c|c|c|c|}
\hline \multirow{2}{*}{ Variables } & \multicolumn{2}{|c|}{ Women } & \multicolumn{2}{|c|}{ Men } \\
\hline & $\mathrm{n}$ & $\%$ & $\mathrm{n}$ & $\%$ \\
\hline \multicolumn{5}{|l|}{ Occupation $^{3}$} \\
\hline manual worker & 93 & 23.5 & 100 & 32.2 \\
\hline manual/non-manual worker & 84 & 21.3 & 72 & 23.2 \\
\hline clerks & 128 & 32.4 & 68 & 21.9 \\
\hline managers & 75 & 19.0 & 60 & 19.3 \\
\hline freelance professions & 6 & 1.5 & 9 & 2.9 \\
\hline unemployed & 0 & 0.0 & 2 & 0.6 \\
\hline never worked & 9 & 2.3 & 0 & 0.0 \\
\hline \multicolumn{5}{|l|}{ Supervisor position ${ }^{4}$} \\
\hline no & 259 & 64.8 & 156 & 49.5 \\
\hline yes & 141 & 35.2 & 159 & 50.5 \\
\hline
\end{tabular}

${ }^{1} \mathrm{Chi}^{2}=34.1, \mathrm{df}=3, \mathrm{p}<0.05$.

${ }^{2} \mathrm{Chi}^{2}=29.5, \mathrm{df}=2, \mathrm{p}<0.05$.

${ }^{3} \mathrm{Chi}^{2}=23.1, \mathrm{df}=6, \mathrm{p}<0.05$.

${ }^{4} \mathrm{Chi}^{2}=16.8, \mathrm{df}=1, \mathrm{p}<0.05$.

Table 2. Distribution of effort-reward imbalance indicators and job demand-control model indicators in baseline study

\begin{tabular}{|c|c|c|c|c|c|c|}
\hline \multirow{2}{*}{$\begin{array}{l}\text { Model describing psychosocial } \\
\text { conditions of work }\end{array}$} & \multirow{2}{*}{ Psychosocial conditions } & \multicolumn{2}{|c|}{ Women } & \multicolumn{2}{|c|}{ Men } & \multirow{2}{*}{$\begin{array}{c}\text { Cramer } \\
\text { V }\end{array}$} \\
\hline & & $\mathrm{n}$ & $\%$ & $\mathrm{n}$ & $\%$ & \\
\hline \multirow[t]{4}{*}{ Effort-reward imbalance model } & low psychological effort - high reward & 52 & 12.7 & 21 & 6.6 & $0.26^{*}$ \\
\hline & high psychological effort - high reward & 146 & 35.6 & 86 & 27.1 & \\
\hline & low psychological effort - low reward & 146 & 35.6 & 87 & 27.4 & \\
\hline & high psychological effort - low reward & 66 & 16.1 & 123 & 38.8 & \\
\hline \multirow[t]{4}{*}{ Effort-reward imbalance model } & low physical effort - high reward & 162 & 39.5 & 67 & 21.1 & $0.28^{*}$ \\
\hline & high physical effort - high reward & 36 & 8.8 & 40 & 12.6 & \\
\hline & low physical effort - low reward & 166 & 40.5 & 114 & 36.0 & \\
\hline & high physical effort - low reward & 46 & 11.2 & 96 & 30.3 & \\
\hline \multirow[t]{4}{*}{ Job demand-control model } & low psychological demands - high control & 31 & 7.6 & 23 & 7.3 & $0.16^{*}$ \\
\hline & high psychological demands - high control & 105 & 25.6 & 120 & 37.9 & \\
\hline & low psychological demands - low control & 167 & 40.7 & 85 & 26.8 & \\
\hline & high psychological demands - low control & 107 & 26.1 & 89 & 28.1 & \\
\hline \multirow[t]{4}{*}{ Job demand-control model } & low physical demands - high control & 122 & 29.8 & 99 & 31.2 & $0.30^{*}$ \\
\hline & high physical demands - high control & 14 & 3.4 & 44 & 13.9 & \\
\hline & low physical demands - low control & 206 & 50.2 & 82 & 25.9 & \\
\hline & high physical demands - low control & 68 & 16.6 & 92 & 29.0 & \\
\hline
\end{tabular}

$* \mathrm{p}<0.05$. 
had never been employed and 2 men $(0.6 \%)$ who were unemployed at the time of the study were excluded from further analysis.

Distribution of job demand-control and effort-reward models was significantly different between men and women (Table 2). During the 7 year follow-up period, 59 participants $(8.1 \%)$ died, including 21 women (5.1\%) and 38 men (12\%) $(\mathrm{V}=0.13, \mathrm{p}<0.05)$. No significant differences were found in the number of deaths in relation to JDC or ERI indicators, except for the relationship concerning imbalance between physical demands and control in men: those with low physical demands and low control died three times more frequently than those with high control, regardless of the level of demands (Table 3).

The comparison of cumulated survival curves confirmed that men with low physical demands and low control had

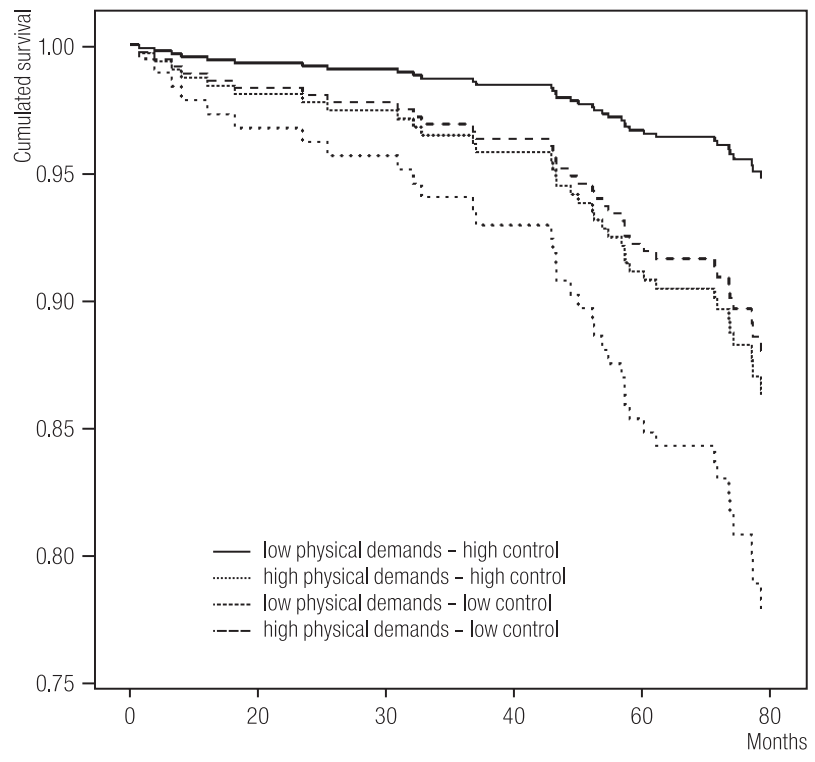

Fig. 2. Cumulated survival curves for "physical job demands control" model for men

Table 3. Distribution of deaths in relation to effort-reward imbalance indicators and job demand-control model indicators

\begin{tabular}{|c|c|c|c|c|c|c|}
\hline \multirow{2}{*}{$\begin{array}{l}\text { Model describing psychosocial } \\
\text { conditions of work }\end{array}$} & \multirow{2}{*}{ Psychosocial conditions } & \multicolumn{2}{|c|}{ Women } & \multicolumn{2}{|c|}{ Men } & \multirow{2}{*}{$\begin{array}{c}\text { Cramer } \\
\mathrm{V}^{1}\end{array}$} \\
\hline & & $\mathrm{n}$ & $\%$ & $\mathrm{n}$ & $\%$ & \\
\hline \multirow[t]{4}{*}{ Effort-reward imbalance model } & low psychological effort - high reward & 2 & 9.5 & 2 & 5.3 & W: 0.03 \\
\hline & high psychological effort - high reward & 8 & 38.1 & 10 & 26.3 & M: 0.04 \\
\hline & low psychological effort - low reward & 7 & 33.3 & 12 & 31.6 & \\
\hline & high psychological effort - low reward & 4 & 19.0 & 14 & 36.8 & \\
\hline \multirow[t]{4}{*}{ Effort-reward imbalance model } & low physical effort - high reward & 8 & 38.1 & 5 & 13.2 & W: 0.02 \\
\hline & high physical effort - high reward & 2 & 9.5 & 7 & 18.4 & M: 0.11 \\
\hline & low physical effort - low reward & 8 & 38.1 & 17 & 44.7 & \\
\hline & high physical effort - low reward & 3 & 14.3 & 9 & 23.7 & \\
\hline \multirow[t]{4}{*}{ Job demand-control model } & low psychological demands - high control & 1 & 4.8 & 2 & 5.3 & $\mathrm{~W}: 0.10$ \\
\hline & high psychological demands - high control & 3 & 14.3 & 9 & 23.7 & M: 0.12 \\
\hline & low psychological demands - low control & 8 & 38.1 & 12 & 31.6 & \\
\hline & high psychological demands - low control & 9 & 42.9 & 15 & 39.5 & \\
\hline \multirow[t]{4}{*}{ Job demand-control model } & low physical demands - high control & 4 & 19.0 & 5 & 13.2 & W: 0.08 \\
\hline & high physical demands - high control & 0 & 0 & 6 & 15.8 & M: $0.18^{*}$ \\
\hline & low physical demands - low control & 12 & 57.1 & 17 & 44.7 & \\
\hline & high physical demands - low control & 5 & 23.8 & 10 & 26.3 & \\
\hline
\end{tabular}

${ }^{1}$ The column presents correlation coefficients for the relationship between JDC/ERI model, respectively and the number of deaths, for women (W) and men (M). $* \mathrm{p}<0.05$. 
Table 4. Differences between groups of men with different characteristics of physical job demand and control

\begin{tabular}{|c|c|c|c|c|c|}
\hline \multirow[b]{2}{*}{ Indicators of occupational position } & \multicolumn{4}{|c|}{ Psychosocial conditions of work (\%) } & \multirow[b]{2}{*}{ Cramer V } \\
\hline & $\begin{array}{c}\text { low physical } \\
\text { demands - } \\
\text { high control }\end{array}$ & $\begin{array}{l}\text { high physical } \\
\text { demands - } \\
\text { high control }\end{array}$ & $\begin{array}{l}\text { low physical } \\
\text { demands - } \\
\text { low control }\end{array}$ & $\begin{array}{l}\text { high physical } \\
\text { demands - } \\
\text { low control }\end{array}$ & \\
\hline Education & & & & & $0.35^{*}$ \\
\hline primary school or lower & 4.0 & 6.8 & 23.2 & 24.5 & \\
\hline vocational & 13.0 & 34.1 & 34.1 & 56.4 & \\
\hline high school & 26.0 & 34.1 & 28.0 & 18.1 & \\
\hline university & 57.0 & 25.0 & 14.6 & 1.1 & \\
\hline Continuing of occupational activity & 44.0 & 18.2 & 18.1 & 9.6 & $0.33^{*}$ \\
\hline Occupational position & & & & & $0.34^{*}$ \\
\hline manual worker & 6.1 & 34.1 & 33.8 & 58.1 & \\
\hline manual/non-manual worker & 13.3 & 15.9 & 32.5 & 29.0 & \\
\hline clerk & 32.7 & 29.5 & 20.0 & 11.8 & \\
\hline manager & 48.0 & 20.5 & 13.8 & 1.1 & \\
\hline Job required permanent self-improvement & 90.0 & 79.5 & 53.7 & 55.3 & $0.35^{*}$ \\
\hline Job required a heavy workload & 12.0 & 100.0 & 36.6 & 100.0 & $0.79^{*}$ \\
\hline Job required high psychological effort & 90.0 & 84.1 & 67.1 & 55.3 & $0.33^{*}$ \\
\hline $\begin{array}{l}\text { Unhealthy environment and exposure to } \\
\text { unhealthy agents }\end{array}$ & 36.0 & 100.0 & 29.6 & 100.0 & $0.68^{*}$ \\
\hline Job control & 100.0 & 100.0 & 17.3 & 18.1 & $0.82^{*}$ \\
\hline Job autonomy & 100.0 & 100.0 & 14.8 & 5.3 & $0.90^{*}$ \\
\hline Conflicts between co-workers & 26.0 & 27.3 & 12.3 & 14.9 & $0.16^{*}$ \\
\hline Job satisfaction & 98.0 & 97.7 & 80.2 & 89.4 & $0.25^{*}$ \\
\hline $\begin{array}{l}\text { Positive self-evaluation of social interactions at } \\
\text { workplace }\end{array}$ & 94.0 & 88.6 & 67.9 & 79.8 & $0.27^{*}$ \\
\hline High salaries & 63.6 & 70.5 & 46.9 & 48.9 & $0.18^{*}$ \\
\hline High self-esteem due to occupational status & 70.0 & 77.3 & 29.6 & 34.0 & $0.40^{*}$ \\
\hline $\begin{array}{l}\text { Social (informal) interactions with co-workers } \\
\text { after retirement }\end{array}$ & 70.0 & 75.0 & 47.5 & 52.1 & $0.22 *$ \\
\hline $\begin{array}{l}\text { Continuation of participation in leisure activities } \\
\text { with previous co-workers out of workplace }\end{array}$ & 47.0 & 31.8 & 13.8 & 12.8 & $0.35^{*}$ \\
\hline Visiting workplace & 49.5 & 28.6 & 16.2 & 10.9 & $0.37^{*}$ \\
\hline Number of friends recruited from co-workers & 81.0 & 90.9 & 70.0 & 72.0 & $0.17^{*}$ \\
\hline Number of persons under supervision & & & & & $\begin{array}{l}\text { Man-Whitney } \\
\text { test* }\end{array}$ \\
\hline median & 10.0 & 8.0 & 0.0 & 0.0 & \\
\hline 1 quartile & 1.0 & 0.0 & 0.0 & 0.0 & \\
\hline 3 quartile & 40.0 & 28.0 & 5.0 & 2.0 & \\
\hline
\end{tabular}

$* p<0.05$. 
the lowest survival rates among all analyzed groups (logrank test: $p<0.05)$ (Figure 2).

It was observed that few men with low physical effort and low control had a university education, while many had only primary school education and held mixed manual/ non manual jobs which did not require continuous professional development or high psychological effort. Their occupational positions did not entail autonomy in organizing job activities or having an influence on decisions at work. They reported the lowest job satisfaction in comparison to other categories of workers, and they assessed relationships with co-workers as poor. They also reported poor salaries, and perceived their own occupational positions as low, which significantly influenced their poor selfesteem due to occupational status (Table 4).

The univariate Cox proportional hazard model showed that a significantly higher risk of death was observed only in the case of a disproportion between physical

Table 5. Univariate and multivariate Cox proportional hazard model for imbalance between physical demands and control

\begin{tabular}{|c|c|c|c|c|c|c|c|c|c|c|c|c|}
\hline \multirow{3}{*}{$\begin{array}{l}\text { Psychosocial conditions } \\
\text { of work }\end{array}$} & \multicolumn{6}{|c|}{ Women } & \multicolumn{6}{|c|}{ Men } \\
\hline & \multicolumn{3}{|c|}{ univariate model } & \multicolumn{3}{|c|}{ multivariate model* } & \multicolumn{3}{|c|}{ univariate model } & \multicolumn{3}{|c|}{ multivariate model* } \\
\hline & HR & & $\mathrm{CI}$ & HR & & & HR & & CI & HR & & $\mathrm{CI}$ \\
\hline $\begin{array}{l}\text { Low physical demands - } \\
\text { high control }\end{array}$ & 1.00 & & & 1.00 & & & 1.00 & & & 1.00 & & \\
\hline $\begin{array}{l}\text { High physical demands - } \\
\text { high control*** }\end{array}$ & 2.19 & 0.62 & 7.76 & 2.22 & 0.58 & 8.50 & 2.87 & 0.88 & 9.40 & 2.73 & 0.83 & 9.06 \\
\hline $\begin{array}{l}\text { Low physical demands - } \\
\text { low control** }\end{array}$ & & & & & & & 4.46 & 1.63 & 12.20 & 4.65 & 1.64 & 13.20 \\
\hline $\begin{array}{l}\text { High physical demands - } \\
\text { low control }\end{array}$ & 2.25 & 0.77 & 12.10 & 2.04 & 0.42 & 9.75 & 2.45 & 0.77 & 6.57 & 2.38 & 0.74 & 7.63 \\
\hline
\end{tabular}

* Model adjusted for psychological demands, level of education, psychological wellbeing, and depression.

** Due to lack of deaths in women with high physical demands and high control, groups of women with balance between physical demands and control were combined into one group.

HR - hazard ratio; $95 \% \mathrm{CI}-95 \%$ confidence interval.

Table 6. Univariate and multivariate Cox proportional hazard model for imbalance between psychological demands and control

\begin{tabular}{|c|c|c|c|c|c|c|c|c|c|c|c|c|}
\hline \multirow{3}{*}{$\begin{array}{l}\text { Psychosocial conditions } \\
\text { of work }\end{array}$} & \multicolumn{6}{|c|}{ Women } & \multicolumn{6}{|c|}{ Men } \\
\hline & \multicolumn{3}{|c|}{ univariate model } & \multicolumn{3}{|c|}{ multivariate model* } & \multicolumn{3}{|c|}{ univariate model } & \multicolumn{3}{|c|}{ multivariate model ${ }^{*}$} \\
\hline & \multirow{2}{*}{$\begin{array}{l}\text { HR } \\
1.00\end{array}$} & \multicolumn{2}{|c|}{$95 \% \mathrm{CI}$} & \multirow{2}{*}{$\begin{array}{l}\text { HR } \\
1.00\end{array}$} & \multicolumn{2}{|c|}{$95 \% \mathrm{CI}$} & \multirow[t]{2}{*}{$\mathrm{HR}$} & \multicolumn{2}{|c|}{$95 \% \mathrm{CI}$} & HR & \multicolumn{2}{|c|}{$95 \% \mathrm{CI}$} \\
\hline $\begin{array}{l}\text { Low psychological } \\
\text { demands - high control }\end{array}$ & & & & & & & & & & 1.00 & & \\
\hline $\begin{array}{l}\text { High psychological } \\
\text { demands - high control }\end{array}$ & 0.62 & 0.06 & 6.85 & 0.87 & 0.08 & 9.91 & 0.88 & 0.19 & 4.09 & 0.91 & 0.19 & 4.36 \\
\hline $\begin{array}{l}\text { Low psychological } \\
\text { demands - low control }\end{array}$ & 1.51 & 0.19 & 12.0 & 0.97 & 0.12 & 7.95 & 1.58 & 0.35 & 7.14 & 1.70 & 0.37 & 7.76 \\
\hline $\begin{array}{l}\text { High psychological } \\
\text { demands - low control }\end{array}$ & 2.73 & 0.35 & 21.5 & 3.38 & 0.42 & 27.10 & 2.18 & 0.50 & 9.55 & 2.33 & 0.53 & 10.30 \\
\hline
\end{tabular}

Abbreviations as in Table 5. 
Table 7. Univariate and multivariate Cox proportional hazard model for imbalance between physical efforts and rewards

\begin{tabular}{|c|c|c|c|c|c|c|c|c|c|c|c|c|}
\hline \multirow{3}{*}{$\begin{array}{l}\text { Psychosocial conditions } \\
\text { of work }\end{array}$} & \multicolumn{6}{|c|}{ Women } & \multicolumn{6}{|c|}{ Men } \\
\hline & \multicolumn{3}{|c|}{ univariate model } & \multicolumn{3}{|c|}{ multivariate model* } & \multicolumn{3}{|c|}{ univariate model } & \multicolumn{3}{|c|}{ multivariate model $^{*}$} \\
\hline & HR & \multicolumn{2}{|c|}{$95 \% \mathrm{CI}$} & HR & \multicolumn{2}{|c|}{$95 \% \mathrm{CI}$} & HR & \multicolumn{2}{|c|}{$95 \% \mathrm{CI}$} & HR & \multicolumn{2}{|c|}{$95 \% \mathrm{CI}$} \\
\hline $\begin{array}{l}\text { Low physical efforts - high } \\
\text { rewards }\end{array}$ & 1.00 & & & 1.00 & & & 1.00 & & & 1.00 & & \\
\hline $\begin{array}{l}\text { High physical efforts - high } \\
\text { rewards }\end{array}$ & 1.22 & 0.25 & 5.86 & 0.65 & 0.12 & 3.35 & 2.46 & 0.78 & 7.74 & 2.31 & 0.69 & 7.73 \\
\hline $\begin{array}{l}\text { Low physical efforts - low } \\
\text { rewards }\end{array}$ & 1.09 & 0.40 & 3.01 & 0.78 & 0.26 & 2.39 & 2.01 & 0.74 & 5.50 & 2.17 & 0.76 & 6.18 \\
\hline $\begin{array}{l}\text { High physical efforts - low } \\
\text { rewards }\end{array}$ & 1.46 & 0.38 & 5.63 & 0.81 & 0.17 & 3.76 & 1.28 & 0.43 & 3.83 & 1.31 & 0.41 & 4.20 \\
\hline
\end{tabular}

Abbreviations as in Table 5.

Table 8. Univariate and multivariate Cox proportional hazard model for imbalance between psychological efforts and rewards

\begin{tabular}{|c|c|c|c|c|c|c|c|c|c|c|c|c|}
\hline \multirow{3}{*}{$\begin{array}{l}\text { Psychosocial conditions } \\
\text { of work }\end{array}$} & \multicolumn{6}{|c|}{ Women } & \multicolumn{6}{|c|}{ Men } \\
\hline & \multicolumn{3}{|c|}{ univariate model } & \multicolumn{3}{|c|}{ multivariate model* } & \multicolumn{3}{|c|}{ univariate model } & \multicolumn{3}{|c|}{ multivariate model* } \\
\hline & HR & \multicolumn{2}{|c|}{$95 \% \mathrm{CI}$} & HR & \multicolumn{2}{|c|}{$95 \% \mathrm{CI}$} & HR & \multicolumn{2}{|c|}{$95 \% \mathrm{CI}$} & HR & \multicolumn{2}{|c|}{$95 \% \mathrm{CI}$} \\
\hline $\begin{array}{l}\text { Low psychological efforts - } \\
\text { high rewards }\end{array}$ & 1.00 & & & 1.00 & & & & & & 1.00 & & \\
\hline $\begin{array}{l}\text { High psychological efforts - } \\
\text { high rewards }\end{array}$ & 1.34 & 0.28 & 6.45 & 2.42 & 0.48 & 12.30 & 1.25 & 0.27 & 5.72 & 1.44 & 0.30 & 6.85 \\
\hline $\begin{array}{l}\text { Low psychological efforts - } \\
\text { low rewards }\end{array}$ & 1.30 & 0.27 & 6.24 & 0.91 & 0.19 & 4.41 & 1.38 & 0.31 & 6.21 & 1.48 & 0.32 & 6.79 \\
\hline $\begin{array}{l}\text { High psychological efforts - } \\
\text { low rewards }\end{array}$ & 1.63 & 0.30 & 8.91 & 2.10 & 0.38 & 11.80 & 1.27 & 0.29 & 5.58 & 1.53 & 0.34 & 6.88 \\
\hline
\end{tabular}

Abbreviations as in Table 5.

demands and control in men with low physical demands and low control, compared to those with low physical demands and high control, treated as the reference group $(\operatorname{Exp}(B)=4.46,95 \%$ CI: 1.63-12.2). However, both in men and women, in all groups, the risk of death was higher than in the reference group, though these differences were not significant. After adjustment for psychological demands and other confounders, which seemed to have a significant impact on the risk of death, the impact of an imbalance between physical demands and control on the risk of mortality still remained significant (Table 5).
The imbalance in the relationship between psychological demands and job control (Table 6), as well as that of the relationship between both psychological or physical efforts and rewards, was found to have no significant impact on the risk of all-cause deaths (Tables 7 and 8).

\section{DISCUSSION}

The results show that only men with low physical demands and low control were at significantly higher risk of death than those with low physical demands and high control (reference category). However, men with high physical 
demands (irrespective of the level of control) were associated with risk of death about 2.5 times higher than that of the reference group. A similar situation was observed in women - those with balanced physical demands and control, as well as those with high physical demands and low control, experienced a risk of death two-fold greater than that of the reference category. This resembles the relationship between job demand-control model and selfrated health, where women with low psychological demands and high control had the best self-rated health out of all women analyzed in the baseline study [26].

Patterns of differences between these categories concerning the risk of death are similar to the patterns of relationships observed in HRQoL level at the beginning of old age. Imbalance between effort and reward did not influence the risk of death in men. Neither imbalance between demands and control, nor effort-reward imbalance influenced the risk of death in women. No similarity was detected between patterns of risk of death and HRQoL at the beginning of older age in women.

A comparison between these results and other studies demonstrates that the identified relationship between job stress and mortality still indicates controversial associations [32,33]. In 2012 Backe et al. [34] performed a systematic review of 26 articles, investigating 20 study cohorts, which analyzed the role of psychosocial stress at work in the development of cardiovascular diseases [27,35-37]. The review revealed moderate evidence that stress at work is related to cardiovascular morbidity and mortality [38]. The strength of association depended on the stress model used in the study and the population or subgroup examined. Kuper et al. [39] confirmed the effect of the effort-reward model on cardiovascular morbidity, but not on mortality.

Job demands were not associated with coronary heart disease (CHD) mortality in the Western Electric Study. In the Whitehall Study, low job control was significantly associated with an increasing risk of CHD both in men and women
[34]. A study performed by Kivimaki [40] confirmed that high job strain and effort-reward imbalance seem to increase the risk of cardiovascular mortality.

The impact of job strain on a 10-year incidence of CHD and total mortality examined in 1711 men and 1328 women aged 18-77 participating in the Framingham Offspring Study [41] did not support high job strain as a significant risk factor for coronary heart disease or death in men and women. Contrary to expectations, the findings showed that women with active job strain (high demands-high control) had a risk of CHD (95\% CI: 1.1-1.72) 2.8 times greater than women with high job strain (high demands-low control). For men, high education, personal income and occupational prestige were related to decreased risk of total mortality. For men, job strain was not associated with morbidity or total mortality over 10 years of follow-up. Job demands were not associated with either total mortality or the 10-year incidence of CHD in women [41].

The relation between unemployment and all-cause mortality has also been studied very carefully [42]. Systematic reviews and meta-analyses have confirmed that the relationship is higher for older men but still lower than for those in early and middle careers, as a result of a smaller net increase in stress among elders, who often hold jobs with higher stress levels and who may have been contemplating retirement [42].

The present study performed in Polish citizens at the beginning of old age (65 years old) with a 7-year follow-up observation of mortality patterns has some limitations: first of all, questions used for job stress model evaluation were not based on original versions used by Karasek and Siegrist, even if they covered all items characteristic for both job stress models. Other authors trying to explain the relationship between job stress and health outcomes also used measures different from Karasek's and Siegrist's measures [43]. The lack of support of the clear relation between both models measuring job stress and mortality risk could also have been significantly influenced by the 
retirement status of the majority of individuals during the baseline study period, as for them, the completed occupational activity meant lack of everyday exposure to a poor psychosocial work environment, they may have been able to cope with negative feelings regarding poor experiences in their past jobs. The study did demonstrate that individuals with lowest occupational position were at a higher risk of death and thus it supports the well-documented relationship between poor socio-economic status in the lifecourse and higher risk of death in older age.

\section{REFERENCES}

1. Nakao M. Work-related stress and psychosomatic medicine. Biopsychosoc Med 2010;4(1):4. DOI: 10.1186/1751-0759-4-4.

2. Rahkonen O, Laaksonen M, Martikainen P, Roos E, Lahelma E. Job control, job demands, or social class? The impact of working conditions on the relation between social class and health. J Epidemiol Community Health 2006(1);60:50-4.

3. Fujishiro K, Diez Roux AV, Landsbergis P, Baron S, Barr RG, Kaufman JD, et al. Associations of occupation, job control and job demands with intima-media thickness: The MultiEthnic Study of Atherosclerosis (MESA). Occup Environ Med 2011;68(5):319-26. DOI: 10.1136/oem.2010.055582.

4. Malinauskiene V, Leisyte P, Malinauskas R, Kirtiklyte K. Associations between self-rated health and psychosocial conditions, lifestyle factors and health resources among hospital nurses in Lithuania. J Adv Nurs 2011;67(11):2383-93. DOI: 10.1111/j.1365-2648.2011.05685.x.

5. Kasl VK, Jones BA. The impact of job and retirement on health. In: Berkman LF, Kawachi I, editors. Social Epidemiology. Oxford: Oxford University Press; 2000. p. 95-117.

6. Hanebuth D, Meinel M, Fischer JE. Health-related quality of life, psychosocial work conditions, and absenteeism in an industrial sample of blue- and white-collar employees: A comparison of potential predictors. J Occup Environ Med 2006;48(1):28-37.

7. De Jonge J, Bosma H, Peter R, Siegrist J. Job strain, effortreward imbalance and employee well-being: A large-scale crosssectional study. Soc Sci Med 2000;50(9):1317-27.
8. Marmot M, Theorell T, Siegrist J. Work and coronary heart disease. In: Stansfeld S, Marmot M, editors. Stress and the Heart. Psychosocial pathways to coronary heart disease. London: BMJ Book; 2002. p. 50-71.

9. Netterstrøm B, Kristensen TS, Sjøl A. Psychological job demands increase the risk of ischaemic heart disease: A 14-year cohort study of employed Danish men. Eur J Cardiovasc Prev Rehabil 2006;13(3):414-20.

10. Siegrist J, Peter R, Junge A, Cremer P, Seidel D. Low status control, high effort at work and ischemic heart disease: prospective evidence from blue-collar men. Soc Sci Med 1990;31(10):1127-34.

11. Karasek RA. Job demands, job decision latitude and mental strain: implications for job redesign. Adm Sci Q 1979;24: 285-308.

12. Siegrist J, Siegrist K, Weber I. Sociological concepts in the etiology of chronic disease: The case of ischemic heart disease. Soc Sci Med 1986;22(2):247-53.

13. Siegrist J.Adverse health effects of high-effort/low-reward conditions. J Occup Health Psychol 1996;1(1):27-41.

14. Van Vegchel N, de Jonge J, Bosma H, Schaufeli W. Reviewing the effort-reward imbalance model: Drawing up the balance of 45 empirical studies. Soc Sci Med 2005;60(5):1117-31.

15. Huang GD, Feuerstein M, Sauter SL. Occupational stress and work-related upper extremity disorders: Concepts and models. Am J Ind Med 2002;41:298-314.

16. Siegrist J, Starke D, Chandola T, Godin I, Marmot M, Niedhammer I, et al. The measurement of effort-reward imbalance at work: European comparisons. Soc Sci Med 2004;58(8):1483-99.

17. Calnan M, Wadsworth E, May M, Smith A, Wainwright D. Job strain, effort-reward imbalance, and stress at work: Competing or complementary models? Scand J Public Health 2004;32:84-93.

18. Lindeberg SI, Rosvall M, Choi BK, Canivet C, Isacsson SO, Karasek R, et al. Psychosocial working conditions and exhaustion in a working population sample of Swedish middle-aged men and women. Eur J Public Health 2011;21(2):190-6. 
19. Kouvonen AM, Väänänen A, Woods SA, Heponiemi T, Koskinen A, Toppinen-Tanner S. Sense of coherence and diabetes: A prospective occupational cohort study. BMC Public Health 2008;8:46. DOI: 10.1186/1471-2458-8-46.

20. Ota A, Masue T, Yasuda N, Tsutsumi A, Mino Y, Ohara H. Association between psychosocial job characteristics and insomnia: An investigation using two relevant job stress models the demand-control-support (DCS) model and the effortreward imbalance (ERI) model. Sleep Med 2005;6(4):353-8.

21. Ota A, Masure T, Yasuda N, Tsutsumi A, Mino Y, Ohara H, et al. Psychosocial job characteristics and insomnia: A prospective cohort study using the Demand-Control-Support (DCS) and Effort-Reward Imbalance (ERI) job stress models. Sleep Med 2009;10(10):1112-7.

22. Roelen CAM, Weites SH, Koopmans PC, van der Klink JJL, Groothoff JW. Sickness absence and psychosocial work conditions: A multilevel study. Occup Med (Lond) 2008;58(6): 425-30. DOI: 10.1093/occmed/kqn073.

23. Roelen CAM, Schreuder KJ, Koopmans PC, Groothoff JW. Perceived job demands relate to self-reported health complaints. Occup Med (Lond) 2008;58(1):58-63. DOI: 10.1093/ occmed/kqm134.

24. Kopp M, Skrabski Á, Szántó Z, Siegrist J. Psychosocial determinants of premature cardiovascular mortality differences within Hungary. J Epidemiol Community Health 2006;60(9):782-8. DOI: 10.1136/jech.2005.042960.

25. Yu S, Gu G, Zhou W, Wang S. Psychosocial work environment and well-being: A cross-sectional study at a thermal power plant in China. J Occup Health 2008;50(2):155-62.

26. Tobiasz-Adamczyk B, Brzyski P. Psychosocial work conditions as predictors of quality of life at the beginning of older age. Int J Occup Med Environ Health 2005;18(1):43-52.

27. Theorell T. Working Conditions and Health. In: Berkman LF, Kawachi I, editors. Social epidemiology. Oxford: Oxford University Press; 2000. p. 95-117.

28. Yesavage JA, Brink TI, Rose TI, Lum O, Huanh V, Adey M. Development and validation of a Geriatric Depression Screening Scale: A preliminary report. J Psychiatr Res 1983;17:37-49.
29. Van den Bos GAM. Zorgen van en voor chronisch zieken. Amsterdam: Proefschrift Universiteit van Amsterdam; 1989. 30. Kempen GI, Miedema I, Ormel J, Molenaar W. The assessment of disability with the Groningen Activity Restriction Scale. Conceptual framework and psychometric properties. Soc Sci Med 1996;11:1601-10.

31. Neugarten BL, Havighurst RJ, Tobin SS. The measurement of life satisfaction. J Gerontlol 1961;16:134-43.

32. Kivimäki M, Virtanen M, Elovainio M, Kouvonen A, Väänänen A. Work stress in the etiology of coronary heart disease - A meta-analysis. Scand J Work Environ Health 2006;32(6):431-42. DOI: 10.5271/sjweh.1049.

33. Waldenström K, Härenstam A. Does the job demand-control model correspond to externally assessed demands and control for both women and men? Scand J Public Health 2008;36(3):242-9.

34. Backé EM, Seidler A, Latza U, Rossnagel K, Schumann B. The role of psychosocial stress at work for the development of cardiovascular diseases: A systematic review. Int Arch Occup Environ Health 2012;85:67-79. DOI: 10.1007/s00420-0110643-6.

35. Theorell T, Tsutsumi A, Hallquist J, Reuterwall C, Hogstedt C, Fredlund P, et al. The SHEEP Study Group. Decision latitude, job strain, and myocardial infarction: A study of working men in Stockholm. Am J Public Health 1998;88(3):382-8.

36. Wamala S, Mittleman MA, Horsten M, Schenck-Gustafsson K, Orth-Gomer K. Job stress and occupational gradient in coronary heart disease risk in women. The Stockholm Female Coronary Risk Study. Soc Sci Med 2000;51(4):481-9.

37. Peter R, Alfredsson L, Hammar N, Siegrist J, Theorell T, Westerholm P. High effort, low reward, and cardiovascular risk factors in employed Swedish men and women: baseline results from the WOLF Study. J Epidemiol Community Health 1998;52(9):540-7.

38. Heslop P, Smith GD, Metcalfe C, Macleod J, Hart C. Change in job satisfaction, and its association with self-reported stress, cardiovascular risk factors and mortality. Soc Sci Med 2002;54(10):1589-99. 
39. Kuper H, Singh-Manoux A, Siegrist J, Marmot M. When reciprocity fails: Effort-reward imbalance in relation to $\mathrm{CHD}$ and health functioning within the Whitehall II Study. Occup Environ Med 2002;59:777-84.

40. Kivimäki M, Leino-Arjas P, Luukkonen R, Riihimäki H, Vahtera J, Kirjonen J. Work stress and risk of cardiovascular mortality: prospective cohort study of industrial employees. BMJ 2002;325:857. DOI: 10.1136/bmj.325.7369.857.

41. Eaker ED, Sullivan LM, Kelly-Hayes M, D'Agostino RB, Benjamin EJ. Does job strain increase the risk for coronary heart disease or death in men and women? Am J Epidemiol 2004;159(10):950-8.

42. Roelfs DJ, Shor E, Davidson KW, Schwartz JE. Losing life and livelihood: A systematic review and meta-analysis of unemployment and all-cause mortality. Soc Sci Med 2011;72(6):840-54.

42. Burr H, Albertsen K, Rugulies R, Hannerz H. Do dimensions from the Copenhagen Psychosocial Questionnaire predict vitality and mental health over and above the job strain and effort-reward imbalance models? Scand J Public Health 2010;38(3):59-68.

This work is available in Open Access model and licensed under a Creative Commons Attribution-NonCommercial 3.0 Poland License - http://creativecommons.org/ licenses/by-nc/3.0/pl/deed.en. 